\title{
Impact of riparian trees shade on aquatic plant abundance in conservation islands
}

\author{
MAgdi M. Ali ${ }^{1 *}$, SAMAR A. HASSAN ${ }^{2}$, ABDEl-SAMEI M. SHAHEEN $^{1 *}$ \\ ${ }^{1}$ Department of Botany, Faculty of Science at Aswan, South Valley University, \\ Aswan 81528, Egypt \\ ${ }^{2}$ First Cataract Conservation Islands, Natural Protectorates Sector, \\ Egyptian Environmental Affairs Agency, Egypt
}

\begin{abstract}
Temperature, acidity, light conditions, total dissolved salts, conductivity, dissolved oxygen, submerged macrophytes and shade and sun path directions were measured at 23 sites along the River Nile banks with Acacia nilotica growing at water's edge around the First Cataract Conservation Islands. Ceratophyllum demersum and Potamogeton crispus were common in the shaded and unshaded zones, Myriophyllum spicatum and Vallisneria spiralis were found only in the unshaded zone and Azolla filiculoides only in the shaded zone. Banks of the sites surveyed were oriented to five directions (NW, SE, NE, SW, N). There is a significant difference in both the type and density of submerged plants growing under the shade of riparian trees (Acacia nilotica) as compared to unshaded areas. Water column irradiance is the most influential variable dictating the distribution of submerged plants. The area of the shade provided by riparian trees was affected by environmental and/or plant variables. Environmental variables comprised the daily course of the exposition to sun; and plant variables included the area of the tree crown, the height of the tree and geographical position of the tree in relation to sun exposition. Trees on the west bank of the islands at the SW-NE direction have the highest shading effect. The management of tree vegetation might control incoming solar radiation affecting submerged macrophytes.
\end{abstract}

Key words: Acacia nilotica, Ceratophyllum demersum, Potamogeton crispus, Myriophyllum spicatum, Vallisneria spiralis, riparian vegetation, submerged macrophytes, Nile, Egypt

Abbreviations: DWSC - Dry weight standing crop, Zeu - eutrophic depth

\section{Introduction}

Aquatic macrophytes provide food, shelter, and substrate for a variety of organisms in aquatic systems (ALI et al. 2007). However, when aquatic plants grow in undesired abundance they tend to become troublesome aquatic weeds and cause severe aquatic environ-

* Corresponding author, e-mail: magdi_ali_23361@yahoo.com

- Dr Abdel-Samei Shaheen died before the completion of this study in September 2008.

Copyright $^{\circledR} 2011$ by Acta Botanica Croatica, the Faculty of Science, University of Zagreb. All rights reserved. 
mental problems. Profuse infestations of aquatic weeds can restrict boat traffic, interfere with fisheries, affect water flow, increasing sedimentation by trapping silt particles and displace more desirable species (PIETERSE and MurPhy 1990, SAND-JENSEN 1998).

In Egypt, the Nile extends for about $1200 \mathrm{~km}$ from Aswan at the south to the Mediterranean coast at the north. The main stream of the Nile and its Rosetta and Damietta branches includes some 500 islands, which constitute a complex ecosystem. Some of these islands exhibit great diversity in origin, size and structure (EL-HADIDI and HoSNI 2000); therefore, 144 islands were declared as a protected area (Prime Minister's Decree under Law No. 1969/1998). Twelve of these islands are in the Province of Aswan.

The Nile at Aswan $\left(24^{\circ} 05^{\prime} \mathrm{N}, 32^{\circ} 55^{\prime} \mathrm{E}\right)$ is interrupted by about 30 islands varying in size and structure, where the river is deflected westwards and the current becomes stronger, indicating the real beginning of the First Cataract. Before the construction of the old Aswan Dam in 1902 and the Aswan High Dam in the 1960s, most of the First Cataract Islands were intermittently under water. However, now most of them are permanently exposed with loamy-sand deposits between them. These granite islands, among the oldest known islands, support unique assemblages of native species characteristic of the aquatic life in the River Nile (EL-HADIDI and SPRINGUEL 1978). In addition, the islands offer an excellent habitat for many birds, including migratory water birds (BARSY 1993). The area of the First Cataract Islands (Saluga, Ghazal and the small surrounding islands) were declared a conservation area by the Prime Minister's Decree under Law No. 928 in 1986 and has had protected status since then within the Egyptian Environmental Affairs Agency.

The distribution and abundance of aquatic plants are influenced by many factors. Nutrients are the most important factor for submerged plant growth and distribution, although, nutrient enrichment in water could inhibit the growth of some aquatic plants. JOHNSON and OSTROFSKY (2004) demonstrate the importance of sediment characteristics in determining macrophyte community structure. VAN DONK and OTTE (1996) report that fish grazing on macrophytes affected the internal balance among autotrophic components by changing composition and lowering the macrophyte standing crop. MidDELbOE and MARKAGER (1997) and ARMENGOL et al. (2003) reported that water depth is the most important factor influencing water transparency and hence distribution of submerged plants varies with depth. Water velocity not only affects the abundance of submerged plants (ALI et al. 1999), but also controls gas exchange processes (SORRELL and Downes 2004). SPRINGUEL (1981) indicates that definite changes in plant distribution in the area of the First Cataract Islands are associated with the increasing depth of soil deposits due to the sedimentation of fine material suspended in water. This is fundamentally caused by changes in water regimes (e.g. steady water level and slowing water current velocity) due to the damming of the Nile south of Aswan (Ali et al. 1995). Increasing sedimentation by the trappingof silt particles by submerged plants is one of the most significant effects of submerged vegetation (SAND-JENSEN 1998) on the aquatic habitat of the First Cataract Conservation Islands. Sediment deposition in the narrow passages between these islands could merge small islands together, which in turn may lead to the disappearance of this unique aquatic microhabitat, which has been protected for the past 25 years. In addition, it will threaten the distinctive natural aquatic communities characterising them, which are already important from a wildlife or landscape perspective (El-HADIDI and Springuel 1978, El-HADIDI and HosNi 2000). Environmental managers of the First Cataract Conservation Islands are therefore faced 
with the problem of losing habitat due to deposition, the disappearance of aquatic plant communities and the merging of islands. They may need to manage excessive plant growth to maintain and conserve habitat quality and therefore the unique flora around the islands.

According to the Bioclimatic Map of the Mediterranean Zone (1963), the study area is in a true desert climate. The rainfall of this area is not only scanty, but also extremely irregular and variable (KASSAS 1955). The First Cataract Islands are characterised by shallow water of low current velocity and support rich floristic diversity (ALI et al. 1999). The study area supports abundant growth of submerged macrophyte communities, dominated by Ceratophyllum demersum L. and Potamogeton crispus L. (Springuel 1981, Ali et al. 1999). Conservation area of the First Cataract Islands exhibits the lowest eutrophication level and alkalinity of all localities in the Nile (ALI et al. 1999). Ali et al. (1995) provided evidence of the significant relation between plant community composition and structure, and hydrosoil texture (mainly sandy loam) that is strongly associated with water level regime. Their results revealed a sediment-related effect of water level regime on submerged plant community. The important environmental factors are concentrations of hydrosoil calcium, magnesium, organic matter and nitrate (ALI et al. 1995).

Aquatic macrophyte control methods (MurPhy 1988a, b; PIETERSE and Murphy 1990; JADHAV et al. 2008; PALMER et al. 2010) provide studies of aquatic macrophyte abundance and growth (SPEnce 1981, Smart and Barko 1986, SAND-Jensen and MADSEN 1991, Schwarz et al. 1996, Middelboe and Markager 1997, BinZer and SAND-JEnSEN 2002, RAEDER et al. 2010). These authors identified light as a primary factor limiting growth. Moreover, the reduction of light has been considered as a technique for the limitation of excess growth of aquatic macrophytes (DAWSON and KERN-HANSEN 1979, DAWSON 1978, Dawson and Haslam 1983, Dawson 1981, BunN et al. 1998). A vinyl-coated fiberglass screen with a mesh size of 64 apertures $\mathrm{cm}^{-2}$ (Aquascreen Menadri-Southern Corp.commercial product) provided effective control of weeds when applied on the bottom (MAYER 1978, PERKINS et al. 1980, NichOLS and SHAW 1993). When applied on the surface, there are negative effects of artificial shading application; water could become stagnant and depleted of oxygen. Alternatively, riparian vegetation, if planned correctly, can provide valuable habitat for wildlife and erosion protection for the bank. In addition, it affects water temperatures by decreasing the warming of water (SCOTTISH ENVIRONMENT PROTECTION AGENCY 2009).

This study was aimed to examine the effect of shade produced by riparian trees on submerged aquatic macrophytes growing in the River Nile at the First Cataract Conservation Islands, in Upper Egypt. The analysis of the effects of riparian woody vegetation consisting of Acacia nilotica trees on submerged plant communities, might contribute to the optimisation of their potential for wildlife in the river corridor.

\section{Materials and methods}

\section{Sampling regime}

In total, 23 sites were randomly selected along the River Nile banks around the First Cataract Islands, namely: Ghazal Island (3 sites), Saluga Island (5 sites), Awad Island (2 sites), Basma Island (3 sites), Seheil Island (9 sites) and one site Barbar at the west bank of 
the Nile (Fig. 1). All sites selected are colonized by Acacia nilotica growing on the edge of the islands. The survey was made in spring (April to June 2008). The canopies of A. nilotica trees have various shapes and heights above the water, as well as of different orientations to the sun. Data on environmental variables, aquatic macrophytes and A. nilotica trees were collected from each site.

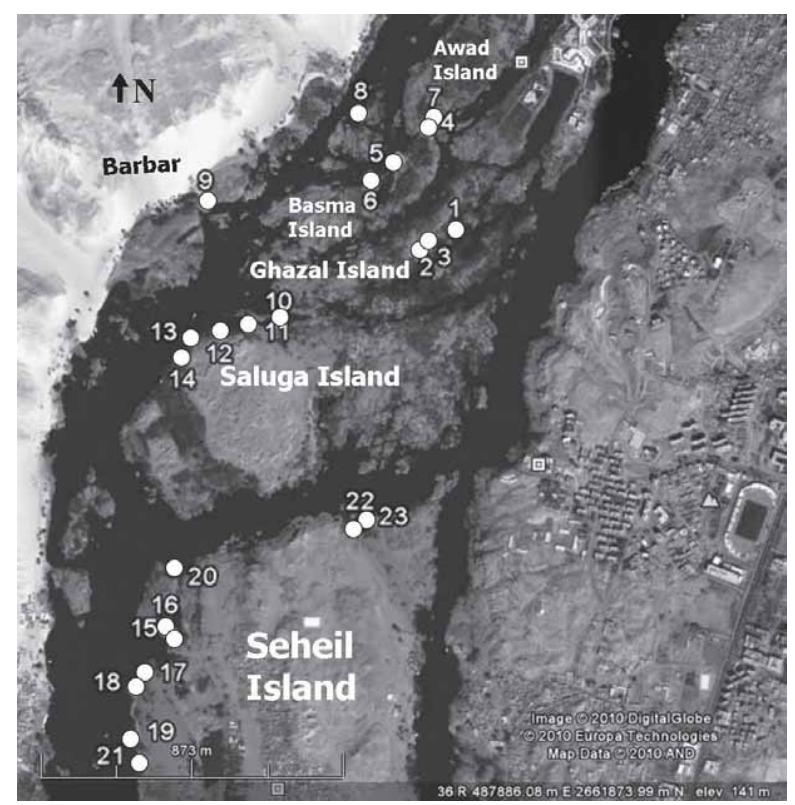

Fig. 1. Location of sites at Aswan; Ghazal Island (1-3); Basma Island (4-6); Awad Island (7-8); Barber (9); Saluga Island (10-14); Seheil Island (15-23).

\section{Aquatic plants sampling}

At each site, samples were collected in the morning from 9:00 to 11:00 am, along fixed transects, positioned rectangular to the shore. A transect extended from shore water edge to cover both zones, shaded and unshaded, at each A. nilotica tree. Each sampling site was divided into two sampling zones, the tree-shaded zone and the unshaded zone. At each zone, submerged plant communities were assessed using the grapnel method to collect relative standing crop samples (five grapnel-hauls per sampling zone). Dry weight standing crop (DWSC) of each species per grapnel haul was determined after air-drying (ambient temperature $45 \mathrm{C}$ ) for a week. This method gives good comparative values of abundance, but does not estimate absolute standing crop per unit area of substrate (MURPHY and EATON 1983).

\section{Environmental variables}

Water samples were collected to get indications of conditions at each site. Seven physico-chemical parameters, namely water depth; temperature and $\mathrm{pH}$ (using a Jenway 3070 portable $\mathrm{pH}$ meter); total dissolved salts and electric conductivity (using Engineered 
System Device model 76) and dissolved oxygen (Winkler's method; APHA 1985), were measured in situ between 09:00 and 11:00 am. Underwater light attenuation was measured using a twin-sensor Skye PAR meter, model SKP 200 with SKP 215 sensors, and light extinction coefficient, a measure of turbidity (Moss 1988), was calculated using the Beer-Lambert Equation:

$$
\mathrm{k} \mathrm{m}^{-1}=\operatorname{loge}(\mathrm{Io} / \mathrm{I}) / \mathrm{d}
$$

where Io = subsurface PAR, I = PAR at depth (d). This equation concerns the exponential decline of light intensity with depth (ARMENGOL et al. 2003). These readings were also used to calculate the depth of the euphotic zone $(\mathrm{Zeu})(\mathrm{Zeu}=3.51 / \mathrm{k})$. The water column irradiance encountered by the submerged plants is the ratio between the euphotic zone depth and the maximum depth (Zmax) (ABERNETHY 1994).

In addition, diurnal sun path direction was estimated in situ by determining the opposite direction of tree shade using a Brunton's compass. The direction of each site surveyed and shaded by A. nilotica trees was estimated, using a Google map, by drawing a tangent on the bank at each site and at the waterside.

\section{Data analysis}

Similarity percentages (SIMPER) were calculated to determine which species contribute most to the observed similarity between the sampling sites surveyed using Community Analysis Package version 4.1.3 (SEABy and HENDERSON 2007). This method uses the Bray-Curtis measure (equation 1) of similarity, related to the complement of the Steinhaus' similarity measure (BEALS 1984):

$$
\frac{\sum_{i=1}^{i=n}\left|S_{i 1}-S_{i 2}\right|}{\sum_{i=1}^{i=n}\left(S_{i 1}+S_{i 2}\right)}
$$

where, $S_{i 1}$ and $S_{i 2}$ are the abundances of species $i$ in samples 1 and 2 respectively.

Kruskal-Wallis H-test was carried out to measure the difference in mean of the total DWSC among the various direction groups in shaded and unshaded sampling sites, using WinSTAT for Excel software (FITCH 2009). This a non-parametric 'analysis of variance' test, which is similar to a one-factor analysis of variance, in that the values for a given dependent variable are placed into, groups according to a given independent variable. Kruskal-Wallis test is applicable to fully randomised designs and can accept groups of unequal size (WARDLAW 1997).

Canonical correspondence analysis (CCA) was carried out using CANOCO for Windows version 4.5 (TER BRAAK and SMILAUER 1998) to explain the relationship between aquatic macrophytes and sampling sites in the light of the measured water variables. The critical value for water column irradiance (Zeu/Zmax) indicates whether light condition is suitable for net macrophyte production was used as useful variable of assessing the role of light in stimulating growth of macrophytes. Total dissolved salts reflect the range of total 
ions; therefore, it was retained in preference to conductivity. Direction of the site bank was dealt with as multiple regression (MONTGOMERY and PECK 1982) and represented by five dummy (nominal) variables $» \mathrm{NW} \ll, » \mathrm{SE} \ll, » \mathrm{NE} \ll, » \mathrm{SW} \ll, » \mathrm{~W} \ll$, and $» \mathrm{~N} \ll$.

\section{Results}

\section{Aquatic macrophytes}

In the water zone shaded by Acacia nilotica trees, only three submerged macrophytes of low dry weight standing crop (DWSC) varied between 0.02 and $3.24 \mathrm{~g} \mathrm{sample}^{-1}$, mean $0.36 \mathrm{~g}$ sample $^{-1}$, SE 0.17) were recorded in seven sites only; the rest of the sites had no submerged macrophytes (Fig. 2). Ceratophyllum demersum dominated four sites (Ghazal Island (Gh1), Basma Island (Ba5, Ba6) and Barbar Island (Br9)) with DWSC ranged between 0.02 and $2.22 \mathrm{~g} \mathrm{sample}^{-1}$ (mean $0.18 \mathrm{~g} \mathrm{sample}^{-1}$, SE 0.1); Potamogeton crispus was only found in two sites in Seheil Island (Se20; DWSC $1.11 \mathrm{~g} \mathrm{sample}^{-1}$ and Se21; DWSC $0.68 \mathrm{~g}$ sample $^{-1}$ ) and Azolla filiculoides dominated Gh3 in Ghazal Island with DWSC $2.4 \mathrm{~g}$ sample ${ }^{-1}$ (Fig. 2).

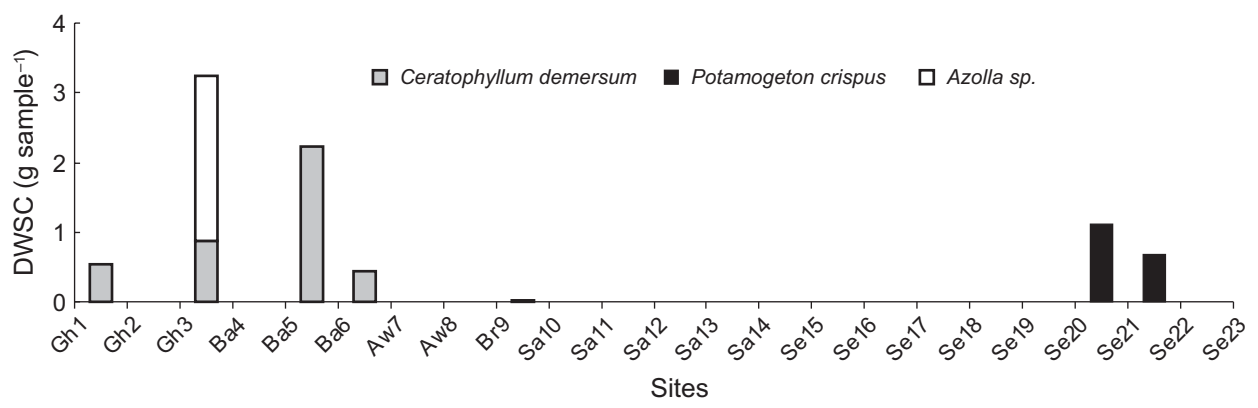

Fig. 2. Dry weight standing crop (DWSC) of submerged macrophytes recorded in the water zone shaded by Acacia nilotica trees.

On the other hand, the unshaded water zone contained more biomass (DWSC varied from 4.4 to $72.1 \mathrm{~g} \mathrm{sample}^{-1}$, mean $29.8 \mathrm{~g} \mathrm{sample}^{-1}$, SE 3.9) and more species of (four species) submerged macrophytes (Fig. 3). Ceratophyllum demersum was noticed in all sites and was the dominant in 20 sites (DWSC varied from 1.9 to $72.1 \mathrm{~g} \mathrm{sample}^{-1}$, mean $22.1 \mathrm{~g}$ sample $^{-1}$, SE 3.9); Myriophyllum spicatum L. was the dominant in Barbar Island (Br9; DWSC $54.6 \mathrm{~g} \mathrm{sample}^{-1}$ ) and was recorded in another six sites (Awad Island (Aw7), Saluga Island (Sa10 and Sa14) and Seheil Island (Se18 and Se19)) with DWSC that ranged between 0.9 and $18.6 \mathrm{~g} \mathrm{sample}^{-1}$ (mean $3.4 \mathrm{~g} \mathrm{sample}^{-1}$, SE 2.4); and P. crispus was found in six sites (Basma Island Ba5, Seheil Island Se15-Se19) with DWSC that varied between 1.6 and $13.2 \mathrm{~g} \mathrm{sample}^{-1}$ and dominated two sites in Seheil Island (Se20 and Se21) with DWSC 13.6 and $16.6 \mathrm{~g} \mathrm{sample}^{-1}$ (mean $4.1 \mathrm{~g} \mathrm{sample}^{-1}$, SE 1.3), respectively. Also, Vallisneria spiralis was recorded in Basma Island (Ba5) and Seheil Island (Se22 and Se 23) having DWSC 1.5, 1.9 and $1.7 \mathrm{~g} \mathrm{sample}^{-1}$, respectively (Fig. 3). Comparing aquatic macrophytes in the two zones, $C$. demersum and $P$. crispus were in common, $M$. spicatum and $V$. spiralis were found only in the unshaded zone and A. filiculoides was only noticed in the shade zone. 


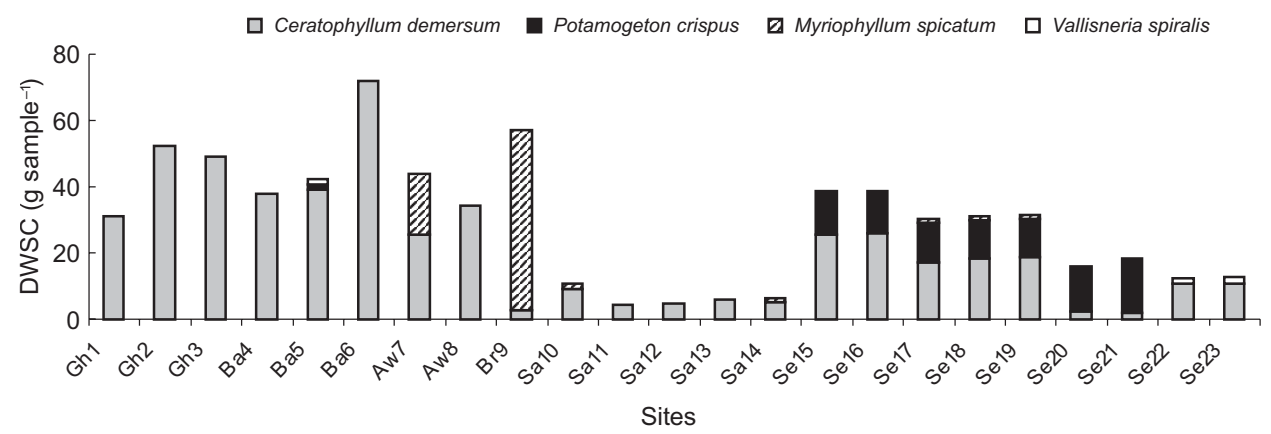

Fig. 3. Dry weight standing crop (DWSC) of submerged macrophytes recorded in the unshaded water zone.

\section{Environmental variables}

At the sampling dates water variables varied slightly between sites ( $\mathrm{pH}$ ranged between 7.58 and 7.73 (mean 7.7, SE 0.007); temperature fluctuated between 19.3 and $21.0 \mathrm{C}$ (mean 20.35, SE 0.097); conductivity varied from 228 to $286 \mu \mathrm{S} \mathrm{cm}^{-1}$ (mean 258.78, SE 3.96); and total dissolved salts ranged between 263 and $280 \mathrm{mg} \mathrm{L}^{-1}$ (mean 273.7, SE 0.65). However, the rest of the variables varied considerably. Dissolved oxygen ranged from 0.96 to $4.08 \mathrm{mg} \mathrm{L}^{-1}$ (mean 2.1, SE 0.204). Water column irradiance varied between 0.26 and 2.03 (mean 0.94, SE 0.096) in shaded zones and fluctuated from 0.35 and 2.34 (mean 1.17, SE 0.113 ) in unshaded zones. If Zeu equals Zmax, then the macrophytes are constantly illuminated and photosynthesis is continuous during the daylight period. If the maximum depth is greater than the depth of the eutrophic zone then the macrophytes spend a proportion of their daylight period in the dark. Water depth ranged between 1.2 to $6.5 \mathrm{~m}$ (mean $2.92 \mathrm{~m}$, SE 0.3) in shaded zones and from 1.5 to $6.5 \mathrm{~m}$ (mean $3.26 \mathrm{~m}$, SE 0.3) in unshaded zones, Water depth was the same in both zones in sites Ba5, Ba6, Aw8, Sa10, Sa14, Se17, Se19, Se18 and $\mathrm{Se} 22$.

During the period of the study (April - June) the shadow-sun path direction was running southeast - northwest with an angle that was $100^{\circ}$ in April, $120^{\circ}$ in May and $160^{\circ}$ in June. Banks of the sites surveyed were of five directions; namely NW (Gh3, Ba4, Ba5, Ba6, Sa13, Se15, Se17, and Se18), SE (Gh1, Gh2, Aw7, Br9, and Se16), NE (Se20 and Se22), SW (Aw8 and Se23), W (Se19 and Se21), and N (Sa10, Sa11, Sa12 and Sa14).

The SIMPER analysis identifies those species, which contribute the most to the similarity between samples (Tab. 1). The SIMPER analysis indicates that $C$. demersum and $P$. crispus are the commonest species in the sites surveyed. Their abundance explains $99 \%$ of the similarity between the sampling sites. C. demersum contributes $90 \%$ to the similarity between the sampling sites, while $P$. crispus only contributes $9.2 \%$ in both shade and unshaded water zones.

Kruskal-Wallis test indicated no significant differences between the five direction groups using total DWSC of macrophytes collected from the shaded zones $(H$-value $=$ 3.617 , and $P=0.606)$. However, differences were very significant between direction groups and total DWSC of macrophytes collected from the unshaded zones $(H$-value $=$ 13.465, $P=0.019)$. 
Ali M. M., Hassan S. A., Shaheen A.-S. M.

Tab. 1. Summary of SIMPER analysis of 46 sampling sites from both shaded and unshaded zones.

\begin{tabular}{lcccc}
\hline Species & $\begin{array}{c}\text { Average } \\
\text { Abundance }\end{array}$ & $\begin{array}{c}\text { Average } \\
\text { Similarity }\end{array}$ & $\begin{array}{c}\text { Contribution } \\
\%\end{array}$ & $\begin{array}{c}\text { Cumulative } \\
\%\end{array}$ \\
\hline Ceratophyllum demersum & 11 & 11 & 90 & 90 \\
Potamogeton crispus & 2.1 & 1.1 & 9.2 & 99 \\
\hline
\end{tabular}

Unassigned Average Similarity $=12$

CANOCO programme encountered only vegetated sampling sites (30 sites) into CCA, while sites without macrophytes (16 sites from the shaded zone) were not included in the analysis. The environmental variables considered in the CCA explained only $38.5 \%$ of the total plant distribution and the species-environmental biplot explained $86.2 \%$ of the total variation contained in the first two axes. The CCA ordination diagram (Fig. 4) indicates that water column irradiance is the most influential variable dictating the distribution of submerged macrophytes in the First Cataract Islands, while dissolved oxygen (DO) is of least importance. The CCA diagram indicates that sites from either shaded or unshaded zones that have high water column irradiance, i.e. of low water depth and high eutrophic

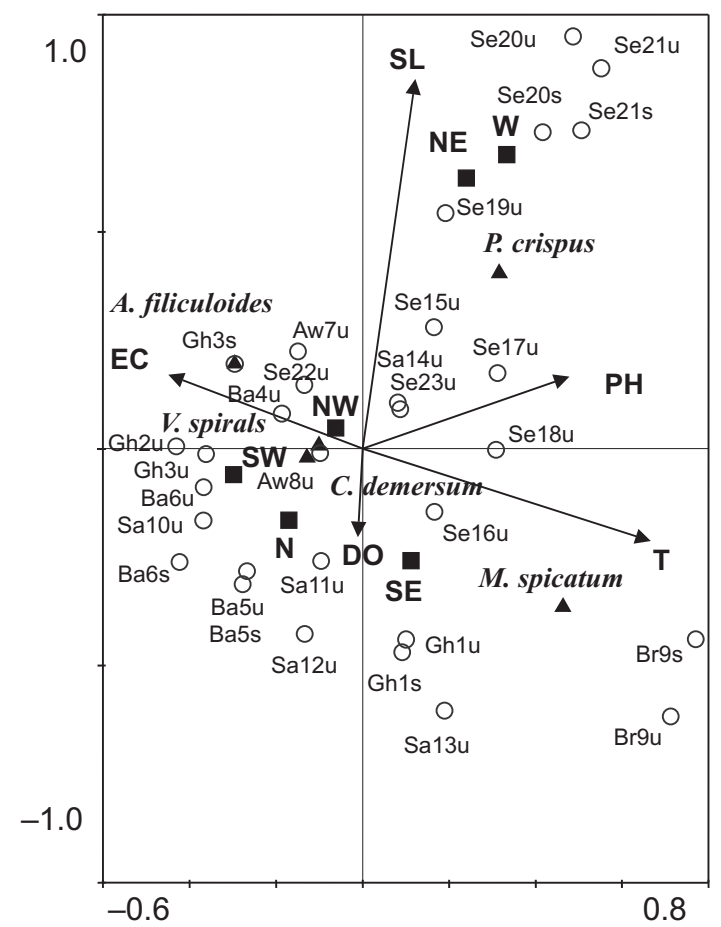

Fig. 4. Canonical Correspondence Analysis (CCA) ordination triplot of submerged macrphytes (ê) recorded in shaded (s) and unshaded (u) zones in the sampling sites (ý) surveyed in relation to the water variables measured (arrows): $\mathbf{S L}$ - water column irradiance, $\mathbf{T}$ - temperature, EC - electrical conductivity, DO - dissolved oxygen; site directions (<): NW, SE, $\mathrm{NE}, \mathrm{SW}, \mathrm{W}$, and N. 
light values (Zeu/Zmax ratio > 1) are characterised by P. crispus (e.g. Se19u, Se20s, Se21s, $\mathrm{Se} 20 \mathrm{u}, \mathrm{Seu} 21 \mathrm{u}$ ) and those of lower water column irradiance (i.e. of high water depth and low eutrophic light values) are characterised by $C$. demersum and/or M. spicatum (e.g. Ba5s, Ba5u, B6s, Ba6u, Ch1s, Gh1u, Br9s, Br9u). Sites with P. crispus are of NE and W and have the highest $\mathrm{pH}$ and low dissolved oxygen values. $C$. demersum, situated in the middle of the diagram, is the most common species in both shaded and unshaded sites. These sites are mainly located on banks facing the NW direction. This is indicated by the position of the nominal variable NW, which is also, situated close to the centre of the programme close to $C$. demersum point. These sites were characterised by moderate values of all the environmental variables measured. The CCA diagram showed that sites of SE direction (right bottom) were distinguished by having $M$. spicatum. These sites were differentiated by having low water column irradiance and high temperature (T) and dissolved oxygen (DO). V. spiralis was found in sites from the unshaded zones of NW and SW directions and of low water dissolved oxygen and temperature, but of high water electrical conductivity (EC). A. filiculoides was only recorded in one sampling site (Gh3), which was of NW direction and characterised by the highest light extinction coefficient (i.e. lowest transparency), temperature and dissolved oxygen.

\section{Discussion}

Several studies have reported the beneficial functions of trees on the edges of water bodies such as thermal buffering, provision of shade, nutrient interception, storage and release enhancement of bank stability, provision of habitat and food for terrestrial and aquatic species and improving sediment regimes (BunN et al. 1999, PuSEY and ARTHINGTON 2003, Hudson and HARding 2004, SøviK and SyVERSEN 2008). Riparian zones represent areas of strong biological, physical and chemical interaction between terrestrial and aquatic ecosystems. Habitat structure is more diverse in sites where natural riparian vegetation is present (BELTRÃO et al. 2009). Water shaded by riparian trees is cooler and contains more dissolved oxygen; roots of riparian vegetation provide spawning sites for fish and the associated invertebrates are a significant food resource for them (HARPER et al. 1995); however, too dense a tree cover completely eliminates submerged macrophytes and hence other aquatic biota associated with them. Similarly, in the present study CCA indicates that site banks facing the NW direction (e.g. Gh3, Ba5, Ba6, Sa13), the opposite direction to sun path (SE) that characterised by low water column irradiance, have the lowest water temperature and high dissolved oxygen. Most of the shaded zones (five out of eight) in sites of NW direction, opposite direction to the sun path (SE), have no vegetation (e.g. Ba4s, Sa13s, Se15s, $\mathrm{Se} 17$ s, and Se18s). Surveys of natural shading by riparian trees have shown significant effects on aquatic plants (YounG et al. 2000). Too much shading results in a suppression of submerged vegetation that is of vital importance to many aquatic biota (e.g. juvenile fish, invertebrates, algae). The Scottish Environment Protection Agency (2009) indicated that the use of shaded and unshaded sections of banks depresses or eliminates aquatic plant growth in the shaded sections and encourages plant growth in the unshaded sections. Similarly, in the present study, aquatic plants growth was depressed or plants were absent in shaded zones, but they were abundant in unshaded zones. There was a significant difference in both the type and density between submerged plants growing shaded and unshaded by riparian trees (Acacia nilotica). M. spicatum and V. spiralis were only found in the un- 
shaded zones. We found Ceratophyllum demersum dominating in both shaded and unshaded zones. It has been previously published (GUPTA and CHANDRA 1996), that the growth rate of this species is attributed to an adequate $\mathrm{CO}_{2}$ level and the tolerance to low light intensity. In the present study, CCA triplot suggested that site banks of SE directions that facing the sun path are of low water column irradiance, which was due to deep water characterising them. These deep-water sites are dominated by $C$. demersum or $M$. spicatum. Similarly, JOHNSON and OSTROFSKY (2004) found that $C$. demersum was the most frequently encountered species at all depths with highest relative importance in the deeper sites. The findings of the present study also agree with those of KAUTSKY (1988) who pointed to the high ability of $C$. demersum to grow in adverse condition and stated that $C$. demersum is abundant in all sites where other aquatic species are rarely present. Ceratophyllum demersum has a suitable morphology for light interception and longevity (GRIME 1979). These results suggest that $C$. demersum and $M$. spicatum are stress-tolerant, which are in line with other researches (FRANK 1975, SEGRETAIN 1996).

Water variables varied slightly between sites, which could be attributed to the physical conditions in the River Nile at the First Cataract Conservation Islands, as well as the fixed sampling time (between 9:00 - 11:00 am). Rate of oxygen released by submerged macrophytes are enhanced by light (SAND-JENSEN et al. 1982, CARPENTER et al. 1983). This may explain high dissolved oxygen values recorded in sites associated with macrophyte DWSC (e.g. at Ba6 DWSC is $72.1 \mathrm{~g} \mathrm{sample}^{-1}$ ). In these sites, euphotic depth (Zeu) almost equals the maximum depth (Zmax), which allows constantly illumination and continuous photosynthesis of submerged macrophytes during the daylight period. High light intensity promotes growth of submerged macrophytes and allows higher photosynthetic rate, converting $\mathrm{CO}_{2}$ to $\mathrm{O}_{2}$ (KITAYA et al. 2003). Sites having high macrophyte DWSC are dominated by C. demersum, which is well known as oxygen generator (HAN and RUNDQUIST 2003).

We can conclude that sites of various light intensities supported vegetation of different composition and abundance. In the present study, riparian Acacia nilotica trees provided natural shading limiting the growth of submerged aquatic plants, otherwise difficult to manage. The type and height of tree required for shade is dependent on the width and the cross-section of the water body (DAWSON 1978, WILLIAMSON et al. 1990). In the present study, the area of shade provided by a riparian tree is affected by environmental and/or plant variables. In addition to the width and the cross-section of the water body, environmental variables comprise daily earth rotation around its axis and seasonal variation in the angle between the Earth's axis and the Sun-Earth path; and plant variables that include the projected area of the tree-crown, height and geographical position of the tree in relation to the Sun-Earth path. The present study indicated that highest shade effect of riparian trees could be achieved by planting trees on the west bank of the islands at the Southwest-Northeast direction, which perpendicularly obstructs the sun path that runs Southeast-Northwest.

\section{Acknowledgements}

This work was supported by the Faculty of Science at Aswan, South Valley University and the First Cataract Conservation Islands, EEAA. The authors thank Mr. Mahmoud Hasseib, Director of the Southern Protectorates Sector for facilities provided during the fieldwork. 
We also thank the referees for their critical reviews and helpful suggestions which greatly improved the manuscript. This paper is dedicated to the memory of our friend and colleague

\section{References}

ABERnethy, V., 1994: The functional ecology of euhydrophyte communities of European riverine wetland ecosystems. PhD Thesis, University of Glasgow, Scotland.

Ali, M. M., Hamad, A., Springuel, I. V., Murphy, K. J., 1995: Environmental factors affecting submerged macrophyte communities in regulated waterbodies in Egypt. Archiv für Hydrobiologie 133, 107-128.

Ali, M. M., Springuel, I. V., Yacoub, H. A., 1999: Submerged plants as bioindicators for aquatic habitat qulity in the River Nile. Journal of Union Arab Biologist 9 (B), 403-418.

Ali, M. M., Mageed, A. A., Heikal, M., 2007: Importance of aquatic macrophyte for invertebrate diversity in large subtropical reservoir. Limnologica 37, 155-169.

APHA, 1985: Standard Methods for the Examination of Water and Wastewater. American Public Health Association, New York.

Armengol, J., Caputo, L., Comerma, M., Feijoó, C., García, J.C., Marcé, R., Navarro, E., ORdoÑEZ, J., 2003: Sau reservoir's light climate: relationships between Secchi depth and light extinction coefficient. Limnetica 22, 195-210.

BARSY, S. A., 1993: Ecological study on bird life in Aswan area. MSc Thesis, Faculty of Science at Aswan, Assiut University, Assuit, Egypt.

BEALs, E. W., 1984: Bray-Curtis ordination: an effective strategy for analysis of multivariate ecological data. Advances in Ecological Research 14, 1-55.

Beltrão, G. B. M., Medeiros, E. S. F., RAmos, R. T. C., 2009: Effects of riparian vegetation removal on the structure of the marginal aquatic habitat and the associated fish fauna in a tropical Brazilian reservoir. Biota Neotropica 9/4, 37-44.

BINZER, T., SAND-JENSEN, K., 2002: Production in aquatic macrophyte communities: a theoretical and empirical study of the influence of spatial light distribution. Limnology and Oceanography 47, 1742-1750.

Bunn, S. E., DAvies, P. M., Mosisch, T. D., 1999: Ecosystem measures of river health and their response to riparian and catchment degradation. Freshwater Biology 41, 333-345.

Bunn, S. E., Davies, P. M., Kellaway, D. M., Prosser, I. P., 1998: Influence of invasive macrophytes on channel morphology and hydrology in an open tropical lowland stream, and potential control by riparian shading. Freshwater Biology 39, 171-178.

CArpenter, S. R., Elser, J. J., Olson, K. M., 1983: Effects of roots of Myriophyllum verticillatum on sediment redox conditions. Aquatic Botany, 17, 243-249.

DAwson, F. H., 1978: Aquatic plant management in semi- natural streams: The role of marginal vegetation. Journal of Environmental Management 6, 213-221.

Dawson, F. H., 1981: The reduction of light as a technique for the control of aquatic plants an assessment. Proceedings of the Association of Applied Biologists Symposium Aquatic Weeds and their Control, Oxford, 157-164. 
Dawson, F. H., HASlAM, S. M., 1983: The management of river vegetation with particular reference to shading effects on marginal vegetation. Landscape Planning 10, 147-169.

Dawson, F. H., Kern-Hansen, U., 1979: The effect of natural and artificial shade on the macrophytes of lowland streams and the use of shade as management technique. Internationale Revue der Gesamten Hydrobiologie 64, 437-455.

El-Hadidi, M. N., Hosni, H. A., 2000: Flora Aegyptiaca. In: El Hadidi, M. N. (ed.), Cairo University Herbarium and the Palm Press, Cairo.

El-Hadidi, M. N., Springuel, I., 1978: Plant life in Nubia (Egypt). Plant communities of the Nile islands at Aswan. Taeckholmia 9, 103-109.

FITCH, R., 2009: User's Manual: WinSTAT for Excel Software. R. Fitch Software.

FRANK, P. A., 1975: Competitive interactions among aquatic plants. Proceeding of the Symposium on Water Quality Managers through Biological Control, University of Florida, 24-27.

Grime, J. P., 1979. Plant strategies and vegetation processes. John Wiley and Sons, Chichester.

Gupta, P., Chandra, P., 1996: Response of cadmium to Ceratophyllum demersum L., a rootless submerged plant. Waste Management 16, 335-337.

Han, L., RundQuist, D. C., 2003: The spectral responses of Ceratophyllum demersum at varying depths in an experimental tank. International Journal of Remote Sensing 24, 859-864.

Harper, D., Smith, C., Barham, P., Howell, R., 1995: The ecological basis for the management of the natural river environment. In: HARPER, D.M., FERGUSON, A. J. D. (eds.), The ecological basis for river management. J. Wiley and Sons, New York.

Hudson, H. R., HARDing, J. S., 2004: Drainage management in New Zealand: A review of existing activities and alternative management practices. New Zealand Department of Conservation, Wellington, New Zealand.

JADHAV, A., Hill, M., BYRne, M., 2008: Identification of a retardant dose of glyphosate with potential for integrated control of water hyacinth, Eichhornia crassipes (Mart.) Solms-Laubach. Biological Control 47, 154-158.

Johnson, R. K., Ostrofsky, M. L., 2004: Effects of sediment nutrients and depth on small-scale spatial heterogeneity of submersed macrophyte communities in Lake Pleasant, Pennsylvania. Canadian Journal of Fisheries and Aquatic Sciences 61, 1493-1502.

KASSAS, M., 1955: Rainfall and vegetation in arid North-East Africa. Proceedings of the Symposium on Plant Ecology. UNESCO, Montpellier, Paris, 49.

KAUTSKY, L., 1988: Life strategies of aquatic soft-bottom macrophytes. Oikos 53, 126-135.

Kitaya, Y., OKayama, T., MuraKami, K., TAKeuchi, T., 2003: Effects of CO2 concentration and light intensity on photosynthesis of a rootless submerged plant, Ceratophyllum demersum L., used for aquatic food production in bioregenerative life support systems. Advanced Space Researches 31, 1743-1749.

MAYER, R. J., 1978: Aquatic weed management by benthic semi-barriers. Journal of Aquatic Plant Management 16, 31-33.

Middelboe, A. L., Markager, S., 1997: Depth limits and minimum light requirements of freshwater macrophytes. Freshwater Biology 35, 553-568. 
Montgomery, D. C., Peck, E. A., 1982: Introduction to linear regression analysis. John Wiley and Sons, New York.

Moss, B., 1988: Ecology of fresh waters: Man and medium. Blackwell Scientific Publications, Oxford.

Murphy, K. J., Eaton, J. W., 1983: The effects of pleasure-boat traffic on macrophyte growth in canals. Journal of Applied Ecology 20, 713-729.

MurPhy, K. J., 1988a: Aquatic weed problems and their management: a review. I. The worldwide scale of the aquatic weed problem. Crop Protection 7, 232-248.

MurPHY, K. J., 1988b: Aquatic weed problems and their management: a review. II. Physical control measures. Crop Protection 7, 283-302.

Nichols, S. A., SHAw, B. H., 1993: Review of management tactics for integrated aquatic weed management of Eurasian water milfoil (Myriophyllum spicatum), curlyleaf pondweed (Potamogeton crispus) and elodea (Elodea canadensis). Proceedings 27 Annual Meeting on Aquatic Plant Control Research, Vicksburg, 181-192.

Palmer, W. A., Heard, T. A., Sheppard, A. W., 2010: A review of Australian classical biological control of weeds programs and research activities over the past 12 years. Biological Control 52, 271-287.

Perkins, M. A., Boston, L., Curren, E. F., 1980: The use of fiberglass screens for control of Eurasian water milfoil. Journal of Aquatic Plant Management 18, 13-19.

Pieterse, A. H., Murphy, K. J., 1990: Aquatic weeds: The ecology and management of nuisance aquatic vegetation. Oxford University Press, London.

Pusey, B. J., ARthington, A. H., 2003: Importance of the riparian zone to the conservation and management of freshwater fish: a review. Marine and Freshwater Researches 54, $1-16$.

Raeder, U., Ruzicka, J., Goos, C., 2010: Characterization of the light attenuation by periphyton in lakes of different trophic state. Limnologica 40, 40-46.

SAND-JENSEN, K., 1998. Influence of submerged macrophytes on sediment composition and near-bed flow in lowland streams. Freshwater Biology 39, 663-679.

SAND-JEnSEN, K., MAdSEN, T. V., 1991: Minimum light requirements of submerged freshwater macrophytes in laboratory growth experiments. Journal of Ecology 79, 749-764.

SAnd-Jensen, K., Prahl, C., Stokholm, H., 1982: Oxygen release from roots of submerged aquatic macrophytes. Oikos 38, 349-354.

Schwarz, A. M., Hawes, I., Howard-Williams, C. H., 1996: The role of photosynthesis/light relationships in determining lower depth limits of Characeae in South Island, New Zealand lakes. Freshwater Biology 35, 69-80.

SCOTTISH ENVIRONMENT PROTECTION AGENCY, 2009: Engineering in the water environment good practice guide: riparian vegetation management. Document Reference, WAT-SG$-44,1-47$.

SEABy, R. M. H., Henderson, P. A., 2007: Community analysis package 4.0. PISCES Conservation Ltd, Lymington, UK.

SEgretain, M. H., 1996: Strategies of reproduction, dispersion, and competition in river plants: A review. Vegetatio 123, 13-37. 
SMART, R. M., BARKO, J. W., 1986: Effects of water chemistry on aquatic plants: Growth and photosynthesis of Myriophyllum spicatum L. Technical Report A-86-2, U.S. Army Engineer Waterways Experiment Station. Vickslourg, MS., NTIS No. AD A168 898.

Sorrell, B. K., DownES, M. T., 2004: Water velocity and irradiance effects on internal transport and metabolism of methane in submerged Isoetes alpinus and Potamogeton crispus. Aquatic Botany 79, 189-202.

Søvik, A. K., SyVERSEN, N., 2008: Retention of particles and nutrients in the root zone of a vegetative buffer zone: effect of vegetation and season. Boreal Environmental Research 13, 223-230.

SPENCE, D. H. N., 1981: Light quality and plant responce under water. In: SMITH H. (ed.), Plants and the day light spectrum, 245-275. Academic Press, New York.

SPRINGUEL, I. V., 1981: Studies on the natural vegetation of the islands of the First Cataract at Aswan, Egypt. PhD Thesis, Assiut University, Assiut, Egypt.

Ter BraAk, C.J. F., Smilauer, P., 1998: CANOCO Reference Manual for User's Guide to Canoco for Windows: Software for Canonical Community Ordination (Version 4.0). Microcomputer Power. Ithaca, New York.

VAn Donk, E., OtTe, A., 1996: Effects of grazing by fish and waterfowl on the biomass and species composition of submerged macrophytes. Hydrobiologia 340, 285-290.

Wardlaw, A. C., 1997: Practical statistics for experimental biologists. John Wiley and Sons, Chichester.

Williamson, R. B., Smith, R. K., QuinN, J. M., 1990: The effects of riparian protection on stream form and stability of 6 grazed streams, Southland, New Zealand. Water Quality Centre Publication 19. Hamilton, New Zealand.

Young, R., Strickland, R., Harding, J., Stark, J., Hayes, J., 2000: The Ecology of Spring Creek Cawthron. Report No. 611. Cawthron Institute, Nelson, New Zealand. 